\title{
General self-efficacy level and health behaviours in women over the age of 45 years who have undergone osteoporosis treatment
}

\author{
Mariola Janiszewska ${ }^{1}$, Teresa Kulik ${ }^{1}$, Dorota Żołnierczuk-Kieliszek ${ }^{1}$, Barłomiej Drop ${ }^{2}$, Ewelina Firlej ${ }^{1}$, \\ Ilona Gajewska²
}

${ }^{1}$ Department Health Sciences, Chair of Public Health, Medical University of Lublin, Poland

${ }^{2}$ Department of Computer Science and Medical Statistics, Medical University of Lublin, Poland

${ }^{3}$ The Graduate from Medical University of Lublin, Faculty of Health Science, Lublin, Poland

\begin{abstract}
Introduction: Contemporary people do not follow the civilisation development in every life domain, their lifestyle is not always healthy. Self-efficacy is the factor that plays an important role in undertaking actions towards struggling with the disease.

The aim of the study was to determine the relationship between the general self-efficacy level and health behaviours as well as chosen sociodemographic features in women over the age of 45 years who have undergone osteoporosis treatment.

Material and methods: The study comprised 151 women over the age of 45 years. The research was conducted in 2016 in health care centres in Lublin, a city in south-eastern Poland. The Generalised Self-Efficacy Scale (GSES) by R. Schwarzer, M. Jerusalem and Z. Juczyński and an original questionnaire were used as research tools. The obtained material was subjected to descriptive and statistical analysis. $\chi^{2}$ test, Kruskal-Wallis test, Mann-Whitney Test and Spearman's rank correlation coefficient were all applied.

Results: The analysis of obtained results showed that as much as $73.5 \%$ of the respondents showed very low and low generalised self-efficacy level. On the other hand, only $22.5 \%$ of the examined were characterised by high and very high generalised self-efficacy level. The longer the duration of osteoporosis treatment (rho $=0.251 ; p=0.002$ ) and the better the self-estimation of health status (rho $=0.473 ; p=0.000$ ), the higher the respondents' generalised self-efficacy level. The women's self-efficacy level declined with increasing ailments (rho $=-0.190 ; p=0.019$ ).
\end{abstract}

Conclusions: The generalized self-efficacy level and the health behaviours are not satisfactory.

Key words: osteoporosis, menopause, general self-efficacy level.

\section{Introduction}

Health problems resulting from osteoporosis have been tormenting people for hundreds of years; they were considered to be a natural result of aging and were not dealt with particularly. Civilisation progress, the development of medicine, the increase in life expectancy, the increasing number of elderly people, and negative changes in lifestyle caused the problem to become significant and threaten the health of a large part of the population. Taking into account the scale of the problem, osteoporosis was identified as a civilisation disease, next to circulatory system diseases and cancer [1].

The first definition of osteoporosis is present in the Polish Encyclopaedia by Trzaska, Evert, and Michalski published in the years 1925-1938. Osteoporosis is described there as a disease that makes bones porous and brittle, and creates empty gaps in bone structure, especially in senile bone loss (atrophia senilis ossium) [2].

According to the American National Institutes of Health (NIH), it is a disease of a skeleton characterised by the increased risk of bone fractures as a consequence of reducing bone mechanical resistance. The bone mechanical resistance depends on bone mineral density and the quality of bone tissue [3, 4].

The statement of National Bone Health Alliance Working Group from the year 2015, also indicates that osteoporosis is the illness of a skeleton characterized by low bone resistance which leads to the increased risk of a bone fracture, usually as a consequence of trauma such as falling from a standing position [5]. Similarly the Foundation and National Institutes of Health - NOF/ $\mathrm{NIH}$ (2001) defines osteoporosis as a skeleton disease, characterized by impaired bone resistance $[6,7]$. 
The World Health Organisation has put osteoporosis on $10^{\text {th }}$ position among civilisation diseases of the contemporary world [8]. In Poland, the number of people suffering from osteoporosis is estimated to be more than 6 million, and proportionally it constitutes $1 / 5$ of the whole population over the age of 45 years. $30-40 \%$ of Polish postmenopausal women struggle with osteoporosis [9]. The prevalence of osteoporosis in postmenopausal women and in women above 70 years of age increases considerably [6]. In Europe, postmenopausal women constitute $1 / 3$ of all patients diagnosed with osteoporosis [9].

The risk of developing the disease in women increases in direct proportion to age and doubles with each decade after the age of 65 years. It is estimated that worldwide osteoporosis affects 200 million women, and $20-25 \%$ of them will suffer an injury in the form of a bone fracture. Taking into account the increasing longevity of American, European, as well as Polish women, it should be noted that over 30 years of a woman's life now constitutes the postmenopausal period when the risk of having broken bones is greater because of greater bone mass loss [9].

Osteoporosis belongs to the group of illnesses that do not manifest by characteristic clinical symptoms. The course of the disease is asymptomatic for years while depriving the skeleton of its accumulated resources. The symptoms appear usually as a consequence of bone fractures. The bone fracture often occurs while performing everyday activities [10]. Such a fracture is known as an osteoporotic or low-energy fracture, it emerges as a result of relatively slight injury, which would not cause the break of the bone continuity in a healthy person [6]. Osteoporotic fracture is disproportionate to the force that causes it, which was adopted in the world as falling down from a standing position, or it occurs spontaneously [11]. Just after reaching the threshold of fractures, a clinical image of osteoporosis emerges.

Osteoporosis belongs to the group of diseases with social importance because causing a lot of bone fractures, it unavoidably increases the number of people being ill and dying from osteoporosis complications [12]. Poland is among the countries with high risk of mortality caused by osteoporosis fracture. These fractures were responsible for the deaths of 43,000 people in 2010; $50 \%$ of these deaths occurred as a result of hip fracture (femoral fracture) in women.

The fractures of the hip remain the most dangerous fractures. Every $5^{\text {th }}$ woman and every $4^{\text {th }}$ man dies because of complications of such a fracture within a year. The risk of hip fracture is higher than the risk the breast cancer, uterus cancer and ovarian cancer. The mortality from osteoporosis fractures is higher than the mortality from breast cancer. These fractures constitute the main cost in the treatment of osteoporosis [13].
In order to reduce costs of treatment and improve efficiency of combating osteoporosis, as well as efficient diagnosis, effective prevention and early elimination of risk factors appear to be important. That means proper diet (rich in vitamin $D$ and calcium), supplementation - especially in the case of malabsorption, physical exercise, early mobilisation of bedridden patients, cessation of alcohol overuse and cigarette smoking, stopping or changing the dose of many medicines, the prevention of falls and fractures. Each of the above-mentioned points is extremely significant [14].

Preventive measures, learning healthy behaviours, healthy lifestyle, and the efforts to take over the responsibility for his/her own health by the patient are the primary and most important tasks for health system employees [15]. A substantial role in these actions can be played by the self-efficacy level of the patients.

Prevention of osteoporosis includes primary and secondary prevention. Primary prevention is based on the positive changes of health behaviours in the population, especially concerning nutrition, because achieving the maximum peak bone mass is very efficient in the struggle with osteoporosis. Secondary prevention is targeted towards early detection of the osteoporosis, stopping its progress, and limiting its complications [16].

Osteoporosis is considered to be a diet-related disease. It can be caused by nutrient deficiencies resulting from imbalanced, irrational nutrition or inappropriate food quality [17]. Proper nutrition, supplementation and physical exercise play an important role in osteoporosis prevention [18].

Health behaviours are combined with psychological mechanisms and include the following elements: expectations, predicting, belief, thinking, emotions, personality mechanisms, and behaviour patterns associated with support and improvement of health status. They may result from habits or they may be the answer to social requirements. They may represent the willingness to follow fashion or they may indicate the high level of knowledge and health awareness in the society. Regardless of the reason triggering the positive health behaviours, the obtained result is satisfactory because they improve the health of the individual and society as a whole. Self-efficacy is a factor that affects undertaking health behaviours. Alongside the increase in self-efficacy, motivation, willingness, dedication, and undertaking actions towards health improvement increase as well. Self-efficacy combined with health applies to physical exercise, healthy nutrition, and following doctors' recommendations. It is associated with the probability of becoming ill and the process of recovery $[18,19]$.

Self-efficacy is defined as: the individual's belief about his/her abilities of organizing and controlling actions leading to achieving the specified level of performance. In other words it is: the man's confidence in his abilities to control the events related to him and the 
belief in his possibilities to motivate himself, to mobilize his cognitive potential and suitable behaviours needed for effective task fulfilling [19].

This concept was introduced in 1997 by Albert Badura, who dealt with human behaviour modification. He discovered that a high level of self-efficacy increases the motivation for activity. It refers directly to the action itself, it is controlled by the individual personally, and it reflects the image of individual competence of every man/woman [20]. Motivation, well-being and achievements of the individual are much more dependent on his/her personal beliefs than on actual facts in his/her environment. The higher the individual's self-efficacy level, the more ambitious challenges he or she chooses; his/her level of dedication increases even when facing the failure because what an individual thinks about his/ her own abilities is much more important than the actual abilities an individual possesses [20, 21].

\section{Aim of the study}

The aim of the study was to determine the relationship between the general self-efficacy level and health behaviours as well as chosen sociodemographic features in women over the age of 45 years who have undergone osteoporosis treatment.

\section{Material and methods}

The research was carried out by means of survey method - a poll technique. The study embraced women over the age of 45 years, who had undergone osteoporosis treatment. The youngest respondent was 45 and the oldest was 91 years old (age arithmetic mean 67.88 years). Purposive sampling was used. The study was conducted in 2016 among patients of the following health care centres in Lublin, a city in south-eastern Poland:

- Cardinal Stefan Wyszyński Specialist Provincial Hospital,

- Non-Public Healthcare Centre VIS VITALIS,

- Non-Public Healthcare Centre REUMED.

The research was conducted among the women willing to participate in the study, who after obtaining complete information about the purpose of the study and being assured full anonymity, expressed informed consent to fill out the questionnaires. The Generalised Self-Efficacy Scale (GSES) by R. Schwarzer, M. Jerusalem, and Z. Juczyński and an original questionnaire were used as research tools. The original questionnaire concerned socio-demographic and economic data, as well as the respondents' health behaviours and knowledge concerning osteoporosis. A total of 151 completely and correctly filled out questionnaires were analysed.

Empirical material collected was subjected to de- scriptive and statistical analysis by the use of IBM SPSS Statistics 20 package. $\chi^{2}$ test, Kruskal-Wallis test, Mann-Whitney test and Spearman's rank correlation coefficient were all applied. The statistical differences up to the level $p<0.05$ were marked by * whereas the statistical differences up to the level $p<0.01$ were marked by ${ }^{* *}$. In addition it was described exactly which groups show statistically significant differences between each other.

\section{Results}

The duration of osteoporosis treatment in the examined group varied from one year to 35 years (arithmetic mean: 4.4 years). It is an alarming fact that as many as $31.8 \%$ of respondents were not able to explain what osteoporosis is. The examined women experienced bone deformity and pain (59.5\%), muscle pain (56.8\%), and limited mobility (29.1\%) as the consequences of osteoporosis. Over half of those examined (53\%) had experienced bone fractures. As much as $55 \%$ of the respondents suffered from osteoporosis ailments every day, and $27.8 \%$ suffered a few times a week. Over two thirds of the examined (69.5\%) complained about balance disorders. The majority of the respondents (70.9\%) had undergone a bone densitometry test. Only $43.7 \%$ of the women expressed a positive opinion about the efficacy of the received osteoporosis treatment, and every fifth respondent (19.9\%) expressed a negative opinion; as many as $19.9 \%$ of the respondents did not see any improvement in their well-being after taking the medicines. Over two-thirds of the women $(60.1 \%)$ indicated genetic factors as the reason for their osteoporosis development. Almost half of the respondents (46.6\%) claimed that a lack of physical exercise was the reason for their osteoporosis development, 39.2\% indicated calcium deficiency, $35.1 \%$ vitamin D deficiency, $25.7 \%$ table salt overconsumption, $20.3 \%$ alcohol overuse, and $19.6 \%$ their small body build. Stress (49.3\%), losing the will to live $(43.9 \%)$, and helplessness $(41.9 \%)$ were the most common women's reactions to being diagnosed with osteoporosis. Only $6.6 \%$ of the respondents made a definite change in their health behaviours after being diagnosed with osteoporosis, $41.1 \%$ made small changes, and as many as $52.3 \%$ of the women did not undertake any action to fight their osteoporosis. The patients mostly took medicines to cope with their osteoporosis, and $6 \%$ of them started to exercise regularly. Table 1 shows the type of osteoporosis treatment used in the studied women.

The majority of the respondents took two kinds of medications: vitamin D supplements (72.2\%) and calcium supplements (61.1\%). The use of bisphosphonates was relatively common (27.2\%).

Forty-nine percent of the examined estimated their health status as very good or good, $51 \%$ as bad or very 
bad. As many as $67.5 \%$ of respondents estimated their knowledge on osteoporosis as bad, but did nothing to improve their knowledge. The analysis of the obtained study results showed that the respondents health behaviours towards their disease were not satisfactory.

The analysis of the obtained results showed statistically significant differences between the generalised self-efficacy level and health behaviours in women who had undergone osteoporosis treatment. The generalised self-efficacy level is an important predictor of preventive health behaviours.

The score obtained by the respondents in GSES varied from 15 to 37 points (the arithmetic mean: 23.3 points; Table 2).

It transpired that as much as $29.8 \%$ of respondents were characterised by very low generalised self-efficacy level and $43.7 \%$ by low generalised self-efficacy level. What is interesting, the average level, which is the most prevalent in the population, was represented by only $4 \%$ of the women (Fig. 1).

The statistically significant correlations were established between the generalized self-efficacy level and the variables presented in Table 3. The longer the duration of osteoporosis treatment ( $\mathrm{rho}=-0.251, p=0.002^{\star *}$ ) and the better the self-estimation of health status (rho = $-0.473, p=0.000^{* *}$ ), the higher the generalised self-efficacy level. On the other hand the more often osteoporosis ailments were experienced (rho $=-0,190,0,019^{* *}$ ),

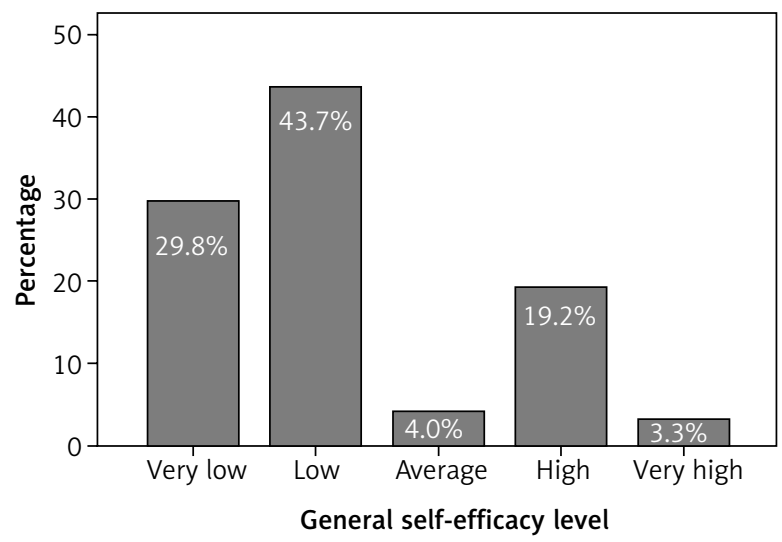

Fig. 1. The categories of general self-efficacy level the higher the age (rho $\left.=-0.203, p=0.012^{\star}\right)$ and the higher level of the education ( $r h o=-0.444, p=0.000^{\star *}$ ), the lower the generalised self-efficacy level.

The correlations between the generalised self-efficacy level and type of medication taken by the women are displayed in Table 4.

Table 1. Medication of osteoporosis in the studied group

\begin{tabular}{lcc}
\hline Medication of osteoporosis & $\boldsymbol{N}$ & $\begin{array}{c}\text { Percentage of } \\
\text { the examined }\end{array}$ \\
\hline Vitamin D supplements & 109 & 72.2 \\
\hline Calcium supplements & 93 & 61.6 \\
\hline Bisphosphonates & 41 & 27.2 \\
\hline $\begin{array}{l}\text { I do not remember the name of the } \\
\text { medicine }\end{array}$ & 37 & 24.5 \\
\hline $\begin{array}{l}\text { Medicines containing oestrogens } \\
\text { Medicines containing oestrogens and }\end{array}$ & 4 & 2.6 \\
\hline $\begin{array}{l}\text { progestogens } \\
\text { The percentages }\end{array}$ & 4 & 2.6 \\
\hline
\end{tabular}

The percentages do not sum up to $100 \%$, because it was a multiple choice question

Table 2. Basic descriptive statistics of obtained GSES scores

\begin{tabular}{cccccc}
\hline $\boldsymbol{N}$ & Min. & Max. & M & Me & SD \\
\hline 151 & 15 & 37 & 23.30 & 21 & 5.62
\end{tabular}

Min. - minimal score; Max. - maximal score; $M$ - arithmetic mean; Me - median; SD - standard deviation

Table 3. The correlations between GSES scores and the respondents' age, education, self-assessment of health status, the frequency of experiencing ailments resulting from osteoporosis and the duration of osteoporosis treatment

\begin{tabular}{lcc}
\hline & \multicolumn{2}{c}{ GSES } \\
\cline { 2 - 3 } & rho & $p$ \\
\hline $\begin{array}{l}\text { The duration of osteoporosis } \\
\text { treatment }\end{array}$ & 0.251 & $0.002^{* \star}$ \\
\hline $\begin{array}{l}\text { Experiencing ailments resulting from } \\
\text { osteoporosis }\end{array}$ & -0.190 & $0.019^{* *}$ \\
\hline $\begin{array}{l}\text { The self-assessment of respondents' } \\
\text { health status }\end{array}$ & 0.473 & $0.000^{* *}$ \\
\hline Age & -0.203 & $0.012^{*}$ \\
\hline Education & -0.444 & $0.000^{* *}$ \\
\hline
\end{tabular}

Table 4. The correlations between the generalized self-efficacy level and type of medication

\begin{tabular}{|c|c|c|c|c|c|}
\hline & & \multirow{2}{*}{$M$} & \multirow[t]{2}{*}{ SD } & \multicolumn{2}{|c|}{ Mann-Whitney Test } \\
\hline & & & & $Z$ & $p$ \\
\hline \multirow{2}{*}{ Vitamin D supplements } & Does not take & 23.95 & 6.01 & \multirow{2}{*}{-0.982} & \multirow{2}{*}{0.326} \\
\hline & Takes & 23.06 & 5.47 & & \\
\hline \multirow{2}{*}{ Calcium supplements } & Does not take & 23.78 & 5.34 & \multirow{2}{*}{-2.360} & \multirow{2}{*}{$0.018^{*}$} \\
\hline & Takes & 23.01 & 5.79 & & \\
\hline \multirow{2}{*}{ Bisphosphonates } & Does not take & 24.14 & 6.03 & \multirow{2}{*}{-2.054} & \multirow{2}{*}{$0.040^{*}$} \\
\hline & Takes & 21.07 & 3.50 & & \\
\hline
\end{tabular}


Table 5. The influence of marital status upon the respondents' scores obtained in General Self-Efficacy Scale

\begin{tabular}{lcc}
\hline Marital status & M & SD \\
\hline Unmarried & 28.25 & 7.80 \\
\hline Married & 24.65 & 6.23 \\
\hline In an extra-marital relationship & 20.58 & 2.75 \\
\hline Divorcee (Separated) & 20.33 & 2.32 \\
\hline Widow & 25.07 & 6.08 \\
\hline Total & 23.30 & 5.62 \\
\hline Kruskal-Wallis Test: $\mathrm{H}=18.574, p=0.001^{* *}$ & &
\end{tabular}

There were no statistically significant correlations found in the generalized self-efficacy level between women taking vitamin D supplements and women who do not take vitamin D supplements. Whereas in the case of calcium supplements, women not taking calcium supplements were characterised by significantly higher generalised self-efficacy level than women who use such supplements. Similarly women who do not take bisphosphonates had significantly higher generalised self-efficacy level than women who took bisphosphonates on a regular basis.

Table 6. The correlations between the frequency of osteoporosis ailments and the frequency of having particular food products, the change in health behaviours, undertaking of physical exercise and daily intake of table salt

\begin{tabular}{|c|c|c|}
\hline & \multicolumn{2}{|c|}{$\begin{array}{l}\text { How often do you suffer from } \\
\text { osteoporosis ailments? }\end{array}$} \\
\hline & Rho & $p$ \\
\hline Have you changed your health behaviours after being diagnosed with osteoporosis? & -0.314 & $0.000^{* *}$ \\
\hline How often do you exercise? & -0.119 & 0.145 \\
\hline $\begin{array}{l}\text { How often do you eat calcium rich food (dairy, eggs, groats, canned fish i.e. sardines, } \\
\text { sprats)? }\end{array}$ & -0.008 & 0.920 \\
\hline $\begin{array}{l}\text { How often do you eat products rich in magnesium (leaf vegetables, wholemeal grainy } \\
\text { products, pulses, bananas, chocolate)? }\end{array}$ & -0.033 & 0.689 \\
\hline How often do you eat products rich in vitamin D (milk, fish, eggs, cream, cheese)? & -0.048 & 0.557 \\
\hline $\begin{array}{l}\text { How often do you eat products rich in vitamin K (spinach, lettuce, cauliflower, cab- } \\
\text { bage, green tea)? }\end{array}$ & -0.181 & $0.026^{*}$ \\
\hline $\begin{array}{l}\text { How often do you eat products rich in vitamin C (rosehips, citrus fruit, berries, toma- } \\
\text { toes, potatoes, parsley)? }\end{array}$ & -0.085 & 0.302 \\
\hline How often do you eat protein rich food (red meat, poultry, fish, nuts)? & -0.082 & 0.318 \\
\hline What is your daily intake of table salt? & 0.197 & $0.015^{*}$ \\
\hline
\end{tabular}

Table 7. The correlations between the duration of osteoporosis treatment and the frequency of having particular food products, the change in health behaviours, undertaking of physical exercise and daily intake of table salt

\begin{tabular}{|c|c|c|}
\hline & \multicolumn{2}{|c|}{$\begin{array}{l}\text { For how many years have you been undergone } \\
\text { osteoporosis treatment? }\end{array}$} \\
\hline & rho & $p$ \\
\hline $\begin{array}{l}\text { Have you changed your health behaviours after being diagnosed with osteo- } \\
\text { porosis? }\end{array}$ & 0.090 & 0.273 \\
\hline How often do you exercise? & 0.094 & 0.253 \\
\hline $\begin{array}{l}\text { How often do you eat calcium rich food (dairy, eggs, groats, canned fish i.e. } \\
\text { sardines, sprats)? }\end{array}$ & 0.399 & $0.000^{* *}$ \\
\hline $\begin{array}{l}\text { How often do you eat products rich in magnesium (leaf vegetables, } \\
\text { wholemeal grainy products, pulses, bananas, chocolate)? }\end{array}$ & 0.247 & $0.002^{* *}$ \\
\hline $\begin{array}{l}\text { How often do you eat products rich in Vitamin D (milk, fish, eggs, cream, } \\
\text { cheese)? }\end{array}$ & 0.228 & $0.005^{* *}$ \\
\hline $\begin{array}{l}\text { How often do you eat products rich in Vitamin K (spinach, lettuce, cauliflower, } \\
\text { cabbage, green tea)? }\end{array}$ & 0.214 & $0.008^{* *}$ \\
\hline $\begin{array}{l}\text { How often do you eat products rich in Vitamin C (rosehips, citrus fruit, berries, } \\
\text { tomatoes, potatoes, parsley)? }\end{array}$ & 0.208 & $0.010^{*}$ \\
\hline How often do you eat protein rich food (red meat, poultry, fish, nuts)? & 0.201 & $0.013^{*}$ \\
\hline What is your daily intake of table salt? & -0.358 & $0.000^{\star *}$ \\
\hline
\end{tabular}


Table 8. The frequency of osteoporosis ailments and the use of dietary supplements

\begin{tabular}{|c|c|c|c|c|c|c|}
\hline \multirow{3}{*}{$\begin{array}{l}\text { Do you use any of the following dietary supplements (vitamin D, magnesium, } \\
\text { calcium, phosphorus, vitamin A, vitamin K, vitamin C, calcitonin, oestrogen)? }\end{array}$} & \multicolumn{4}{|c|}{$\begin{array}{l}\text { How often do the problems } \\
\text { appear? }\end{array}$} & \multirow{2}{*}{\multicolumn{2}{|c|}{ Total }} \\
\hline & \multicolumn{2}{|c|}{ Every day } & \multicolumn{2}{|c|}{ More seldom } & & \\
\hline & $n$ & $\%$ & $n$ & $\%$ & $n$ & $\%$ \\
\hline Yes & 46 & 55.4 & 51 & 75.0 & 97 & 64.2 \\
\hline No & 37 & 44.6 & 17 & 25.0 & 54 & 35.8 \\
\hline Total & 83 & 100.0 & 68 & 100.0 & 151 & 100.0 \\
\hline
\end{tabular}

Test $\chi^{2}: \chi^{2}=6.237, p=0.013^{*}$

Table 9. The frequency of osteoporosis ailments and health behaviours undertaken by the respondents to counteract osteoporosis

\begin{tabular}{|c|c|c|c|c|c|c|}
\hline \multirow{3}{*}{ What do you do to treat your osteoporosis? } & \multicolumn{4}{|c|}{ How often do the problems appear? } & \multirow{2}{*}{\multicolumn{2}{|c|}{$\chi^{2}$ test }} \\
\hline & \multicolumn{2}{|c|}{ Every day } & \multicolumn{2}{|c|}{ More seldom } & & \\
\hline & $n$ & $\%$ & $n$ & $\%$ & $\chi^{2}$ & $p$ \\
\hline I have started regular physical exercise & 1 & 1.2 & 8 & 11.8 & 7.436 & $0.006^{\star *}$ \\
\hline I have stopped drinking alcohol & 11 & 13.3 & 10 & 14.7 & 0.066 & 0.797 \\
\hline I have stopped smoking cigarettes & 23 & 27.7 & 4 & 5.9 & 12.129 & $0.000^{* *}$ \\
\hline I have started to eat more calcium-rich products & 32 & 38.6 & 37 & 54.4 & 3.788 & 0.052 \\
\hline I watch my diet & 11 & 13.3 & 39 & 57.4 & 32.821 & $0.000^{* \star}$ \\
\hline I take recommended medication & 58 & 69.9 & 31 & 45.6 & 9.133 & $0.003^{* *}$ \\
\hline I do not do anything except taking recommended medication & 31 & 37.3 & 34 & 50.0 & 2.440 & 0.118 \\
\hline I take vitamin D supplements and calcium supplements & 50 & 60.2 & 23 & 33.8 & 10.445 & $0.001^{\star \star}$ \\
\hline I often stay in the sunshine & 12 & 14.5 & 14 & 20.6 & 0.986 & 0.321 \\
\hline I avoid sedentary lifestyle & 10 & 12.0 & 8 & 11.8 & 0.003 & 0.957 \\
\hline
\end{tabular}

It transpired that marital status diversified the generalised self-efficacy level in a statistically significant manner (Table 5). The generalised self-efficacy level was found to be lower in divorcees and separated women (20.33) than in married women (24.65) and in widows (25.07). What is interesting, the highest level was found in unmarried women (28.25).

The frequency of osteoporosis ailments correlates significantly with some health behaviours. The higher the daily intake of table salt, the more frequently the osteoporosis ailments were experienced ( $r$ o $=-0.314$, $\left.p=0.000^{\star *}\right)$. However, the bigger changes in health behaviours (rho $=0.197, p=0.015^{\star}$ ) and the more often Vitamin $\mathrm{K}$ rich products were consumed ( $\mathrm{rho}=-0.181$, $\left.p=0.026^{\star}\right)$, the less frequently osteoporosis ailments the were experienced by the examined (Table 6).

The duration of osteoporosis treatment also correlates significantly with some health behaviours. The longer the treatment duration, the more often calcium rich products were consumed ( $\mathrm{rho}=0.399, p=$ $0.000^{\star \star}$ ), as well as magnesium-rich products (rho $=$ $0.47, p=0.002^{\star \star}$ ), vitamin $\mathrm{D}$ rich products (rho $=0.228$, $p=0.005^{\star \star}$ ), vitamin K-rich products (rho $=0.214, p=$ $\left.0.008^{\star \star}\right)$, vitamin C-rich products ( $r$ o $=0.208, p=0.010^{\star}$ ) as well as protein rich products ( $r$ o $=0.201, p=0.013^{\star}$ ). The longer the treatment duration, the smaller the daily intake of table salt (rho $=-0.358, p=0.000^{* *}$ ) (Table 7).

The statistically significant differences were also found between the frequency of osteoporosis aliments and dietary supplement taking $\left(\chi^{2}=6.237, p=0.013^{\star}\right)$. Women who experienced the ailments every day took the supplements less often (55.4\%) than women who did not experience the ailments every day (Table 8).

The statistically significant differences were found between the frequency of osteoporosis ailments and health behaviours undertaken by the respondents to counteract osteoporosis.

The respondents who experience the ailments less often than every day, significantly more often undertook physical exercise $\left(\chi^{2}=7.436, p=0.006^{\star \star}\right)$, and watched their diet $\left(\chi^{2}=32.821, p=0.000^{\star *}\right)$, however, they significantly less often stopped smoking cigarettes $\left(\chi^{2}=12.129, p=0.000^{* *}\right)$, took recommended medication $\left(\chi^{2}=9.133, p=0.003^{\star *}\right)$, took vitamin $\mathrm{D}$ supplements and calcium supplements $\left(\chi^{2}=10.445\right.$, $p=0.001^{\star \star}$ ) (Table 9).

Statistically significant differences were established between the duration of osteoporosis treatment and 
drinking strong coffee and tea by the respondents $\left(\chi^{2}\right.$ $=6.036, p=0.014$ ). $84.4 \%$ of women undergoing osteoporosis treatment for up to 3 years drank strong tea or coffee regularly, whereas among women undergoing osteoporosis treatment for more than 3 years the adequate percentage equals $66.7 \%$ (Table 10 ).

Highly statistically significant differences between the duration of osteoporosis treatment and cigarette smoking were also observed $\left(\chi^{2}=18.155, p=0.000^{\star *}\right)$. The percentage of cigarette smokers was higher among the women who had undergone osteoporosis treatment for up to3 years (37.5\%) than among the women who had undergone treatment for more than 3 years (9.25\%) (Table 11).

Statistically significant differences between the duration of osteoporosis treatment and health behaviours undertaken by the respondents to counteract osteoporosis were also found. Respondents undergoing the treatment for up to 3 years significantly more often: watched their diet $\left(\chi^{2}=11.779\right.$,

Table 10. The duration of osteoporosis treatment and drinking strong coffee and tea

\begin{tabular}{|c|c|c|c|c|c|c|}
\hline \multirow{3}{*}{$\begin{array}{l}\text { Do you drink strong coffee and tea regularly } \\
\text { (more than } 2-3 \text { cups a day)? }\end{array}$} & \multicolumn{4}{|c|}{$\begin{array}{l}\text { For how many years have you been undergone } \\
\text { osteoporosis treatment? }\end{array}$} & \multirow{2}{*}{\multicolumn{2}{|c|}{ Total }} \\
\hline & \multicolumn{2}{|c|}{ up to 3} & \multicolumn{2}{|c|}{ above 3} & & \\
\hline & $n$ & $\%$ & $n$ & $\%$ & $n$ & $\%$ \\
\hline Yes & 54 & 84.4 & 58 & 66.7 & 112 & 74.2 \\
\hline No & 10 & 15.6 & 29 & 33.3 & 39 & 26.8 \\
\hline Total & 64 & 100.0 & 87 & 100.0 & 151 & 100.0 \\
\hline
\end{tabular}

Table 11. The duration of osteoporosis treatment and cigarette smoking

\begin{tabular}{|c|c|c|c|c|c|c|}
\hline \multirow{3}{*}{ Do you smoke cigarettes? } & \multicolumn{4}{|c|}{$\begin{array}{l}\text { For how many years have you been undergone } \\
\text { osteoporosis treatment? }\end{array}$} & \multirow{2}{*}{\multicolumn{2}{|c|}{ Total }} \\
\hline & \multicolumn{2}{|c|}{ up to 3} & \multicolumn{2}{|c|}{ above 3} & & \\
\hline & $n$ & $\%$ & $n$ & $\%$ & $n$ & $\%$ \\
\hline Yes & 24 & 37.5 & 8 & 9.2 & 32 & 21.2 \\
\hline No & 40 & 62.5 & 78 & 89.7 & 118 & 78.1 \\
\hline $\begin{array}{l}\text { I stopped smoking since I was diagnosed with } \\
\text { osteoporosis }\end{array}$ & 0 & 0.0 & 1 & 1.1 & 1 & 0.7 \\
\hline Total & 64 & 100.0 & 87 & 100.0 & 151 & 100.0 \\
\hline
\end{tabular}

Table 12. The duration of osteoporosis treatment and health behaviours undertaken by the respondents to counteract osteoporosis

\begin{tabular}{|c|c|c|c|c|c|c|}
\hline \multirow{3}{*}{ What do you do to treat your osteoporosis? } & \multicolumn{4}{|c|}{$\begin{array}{l}\text { For how many years have you been undergone } \\
\text { osteoporosis treatment? }\end{array}$} & \multirow{2}{*}{\multicolumn{2}{|c|}{$\chi^{2}$ test }} \\
\hline & \multicolumn{2}{|c|}{ up to 3} & \multicolumn{2}{|c|}{ above 3} & & \\
\hline & $n$ & $\%$ & $n$ & $\%$ & $\chi^{2}$ & $p$ \\
\hline I have started regular physical exercise & 2 & 3.1 & 7 & 8.0 & 1.593 & 0.207 \\
\hline I have stopped drinking alcohol & 2 & 3.1 & 19 & 21.8 & 10.786 & $0.001^{\star *}$ \\
\hline I have stopped to smoking cigarettes & 4 & 6.3 & 23 & 26.4 & 10.234 & $0.001^{* *}$ \\
\hline $\begin{array}{l}\text { I have started to eat more calcium-rich prod- } \\
\text { ucts }\end{array}$ & 16 & 25.0 & 53 & 60.9 & 19.172 & $0.000^{\star *}$ \\
\hline I watch my diet & 31 & 48.4 & 19 & 21.8 & 11.779 & $0.001^{\star *}$ \\
\hline I take recommended medication & 41 & 64.1 & 48 & 55.2 & 1.204 & 0.272 \\
\hline $\begin{array}{l}\text { I do not do anything except taking recom- } \\
\text { mended medication }\end{array}$ & 40 & 62.5 & 25 & 28.7 & 17.147 & $0.000^{\star *}$ \\
\hline $\begin{array}{l}\text { I take vitamin D supplements and calcium sup- } \\
\text { plements }\end{array}$ & 37 & 57.8 & 36 & 41.4 & 3.988 & $0.046^{*}$ \\
\hline I often stay in the sunshine & 16 & 25.0 & 10 & 11.5 & 4.719 & $0.030^{*}$ \\
\hline I avoid sedentary lifestyle & 7 & 10.9 & 11 & 12.6 & 0.102 & 0.749 \\
\hline
\end{tabular}


Table 13. The correlations between the self-estimation of health status and the frequency of having particular food products, undertaking of physical exercise and daily intake of table salt

\begin{tabular}{lcc}
\hline & \multicolumn{1}{c}{$\begin{array}{c}\text { The self-estimation of health } \\
\text { status }\end{array}$} \\
\cline { 2 - 3 } & rho & $p$ \\
\hline How often do you exercise? & 0.146 & 0.073 \\
\hline How often do you eat calcium rich food (dairy, eggs, groats, canned fish i.e. sardines, sprats)? & 0.248 & $0.002^{* *}$ \\
\hline $\begin{array}{l}\text { How often do you eat products rich in magnesium (leaf vegetables, wholemeal grainy products, } \\
\text { pulses, bananas, chocolate)? }\end{array}$ & 0.471 & $0.000^{* *}$ \\
\hline How often do you eat products rich in vitamin D (milk, fish, eggs, cream, cheese)? & 0.099 & 0.224 \\
\hline $\begin{array}{l}\text { How often do you eat products rich in vitamin K (spinach, lettuce, cauliflower, cabbage, green } \\
\text { tea)? }\end{array}$ & 0.255 & $0.002^{* *}$ \\
\hline $\begin{array}{l}\text { How often do you eat products rich in vitamin C (rosehips, citrus fruit, berries, tomatoes, pota- } \\
\text { toes, parsley)? }\end{array}$ & 0.402 & $0.000^{\star *}$ \\
\hline How often do you eat protein rich food (red meat, poultry, fish, nuts)? & 0.200 & $0.014^{*}$ \\
\hline What is your daily intake of table salt? & -0.188 & $0.021^{*}$ \\
\hline
\end{tabular}

Table 14. The self-estimation of health status and health behaviours undertaken by the respondents to counteract osteoporosis

\begin{tabular}{|c|c|c|c|c|c|c|}
\hline \multirow{3}{*}{ What do you do to treat your osteoporosis? } & \multicolumn{4}{|c|}{ Self-estimation of health status } & \multirow{2}{*}{\multicolumn{2}{|c|}{$\chi^{2}$ test }} \\
\hline & \multicolumn{2}{|c|}{ good } & \multicolumn{2}{|c|}{ bad } & & \\
\hline & $n$ & $\%$ & $n$ & $\%$ & $\chi^{2}$ & $p$ \\
\hline I have started regular physical exercise & 9 & 12.2 & 0 & 0.0 & 9.958 & $0.002^{* *}$ \\
\hline I have stopped drinking alcohol & 11 & 14.9 & 10 & 13.0 & 0.111 & 0.739 \\
\hline I have stopped to smoking cigarettes & 12 & 16.2 & 15 & 19.5 & 0.274 & 0.601 \\
\hline I have started to eat more calcium-rich products & 51 & 68.9 & 18 & 23.4 & 31.540 & $0.000^{\star *}$ \\
\hline I watch my diet & 26 & 35.1 & 24 & 31.2 & 0.268 & 0.605 \\
\hline I take recommended medication & 40 & 54.1 & 49 & 63.6 & 1.432 & 0.231 \\
\hline I do not do anything except taking recommended medication & 25 & 33.8 & 40 & 51.9 & 5.078 & $0.024^{*}$ \\
\hline I take vitamin D supplements and calcium supplements & 28 & 37.8 & 45 & 58.4 & 6.415 & $0.011^{*}$ \\
\hline I often stay in the sunshine & 9 & 12.2 & 17 & 22.1 & 2.603 & 0.107 \\
\hline I avoid sedentary lifestyle & 14 & 18.9 & 4 & 5.2 & 6.769 & $0.009^{\star \star}$ \\
\hline
\end{tabular}

The percentages do not sum up to $100 \%$, because it was a multiple choice question

$\left.p=0.001^{* \star}\right)$, did nothing except taking recommended medication $\left(\chi^{2}=17.147, p=0.000^{\star *}\right)$, took vitamin $D$ supplements and calcium supplements $\left(\chi^{2}=3.988\right.$, $\left.p=0.046^{*}\right)$, stayed in the sunshine often $\left(\chi^{2}=4.719\right.$, $\left.p=0.030^{\star}\right)$, however, they significantly less often stopped drinking alcohol $\left(\chi^{2}=10.786, p=0.001^{\star *}\right)$ and smoking cigarettes $\left(\chi^{2}=10.234, p=0.001^{\star *}\right)$ (Table 12).

The self-estimation of health status correlates significantly with some health behaviours. The more often products rich in calcium ( $r$ o $=0.248, p=0.002^{\star *}$ ), magnesium ( $r$ o $=0.471, p=0.000^{* *}$ ), vitamin $\mathrm{K}(\mathrm{rho}=$ $\left.0.255, p=0.002^{\star *}\right)$, vitamin $C\left(\right.$ rho $\left.=0.402, p=0.000^{\star *}\right)$ and protein ( $r h o=0.200, p=0.014^{\star}$ ) were consumed, the better self-estimation of the health status of the respondents was. On the other hand the higher the daily intake od table salt (rho $=-0.188, p=0.021^{*}$ ), the worse the self-estimation of health status (Table 13).
Statistically significant differences between the self-estimation of health status and health behaviours undertaken by the respondents to counteract osteoporosis were observed. The respondents, who estimated their health status as good, significantly more often: started regular physical exercise $\left(\chi^{2}=9.958\right.$, $\left.p=0.002^{* *}\right)$, started to eat more calcium-rich products $\left(\chi^{2}=31.540, p=0.000^{\star *}\right)$ and avoided a sedentary lifestyle $\left(\chi^{2}=6.769, p=0.009^{* *}\right)$. On the other hand, they significantly less often: did nothing except taking recommended medication $\left(\chi^{2}=5.078, p=0.024^{\star \star}\right)$ as well as taking vitamin $D$ supplements and calcium supplements $\left(\chi^{2}=6.415, p=0.011^{\star}\right)$ (Table 14).

\section{Discussion}

Nowadays, osteoporosis is described as a social disease because of the increasing number of people suf- 
fering from it and its economic consequences for the whole society [22]. Osteoporosis is considered to be the main disease of the skeletal system. The course of the disease is slow and at the beginning asymptomatic, which constitutes the great danger. Therefore, patients in the initial stage of the disease find out about their osteoporosis as late as they experience the first bone fracture after a relatively mild injury [23]. Sometimes it may be a shock for them. Especially taking into account that osteoporosis is an incurable disease. We can only prevent its negative consequences and alleviate its symptoms. This is why the patient has to learn to live with his/her disease. To be able to do this, the patient has to work on his/her generalised efficacy level to fight the disease. This allows them to implement health behaviours that improve both the physical and psychological health of the person suffering from osteoporosis.

The general self-efficacy level reflects the personal resources of the individual, which helps the individual to cope with problems in various life domains. It allows the prediction of intentions in various fields of life activity including heath behaviours. A literature review within this scope was made by Juczyński [20]. In our study, the more often women experienced osteoporosis ailments and the older they were, the lower their general self-efficacy level was. Experiencing constant pain and older age cause the general health deterioration and general self-efficacy level decrease, which weakens the motivation to undertake further actions.

Self-efficacy level affects the decision-making process and the choice of activities undertaken. A high self-efficacy level protects the individual from emotional exhaustion, ensures better health in the future, and brings greater life satisfaction. Andruszkiewicz, Banaszkiewicz, et al. showed that the generalised self-efficacy level among nurses was average [24]. Our results suggest that $29.8 \%$ of the respondents were characterised by very low self-efficacy level. What is interesting, the average level, which is the most prevalent in the population, was represented by only $4 \%$ of the women. A high self-efficacy level is felt by $19.2 \%$ of the examined and a very high level by $3.3 \%$ of the women. Women with higher education showed lower self-efficacy level. Contrary to the present study, Chodkiewicz and Gruszyńska found no statistical differences between the respondents' education and self-efficacy level [25]. Their study comprised alcohol-addicted patients undergoing treatment. Chodkiewicz and Gruszyńska's study suggests that alcohol-addicted patients with high self-efficacy level had better results in maintaining 12 months of alcohol abstinence.

The self-efficacy level may increase during treatment. It may be described as the determinant of the willingness for changes leading to the improvement of one's health status. Although, when the self-efficacy level is low such changes are more difficult or often doomed to failure right from the beginning. This is because the person undertaking certain action lacks competence or motivation to start the action [26].

Our data show that every fifth respondent (21.2\%) smoked cigarettes. The research conducted by Lewtak and Smolińska on a group of Polish doctors showed that doctors who smoked cigarettes every day were characterised by lower self-efficacy level in comparison to doctors who did not smoke cigarettes every day [27].

It is worth paying attention to the fact that the marital status diversified the generalised self-efficacy level. The generalised self-efficacy level was found to be significantly lower in divorcees and separated women (20.33) than in married women (24.65) and in widows (25.07). The highest level was found in unmarried women (28.25). In Rogala et al.'s study performed on a group of women diagnosed with reproductive organ cancer, statistically significant correlation was found between the marital status and self-efficacy level. Women in relationships showed higher self-efficacy levels in comparison to single women [28].

One of our research assumptions was to find out if younger women were characterised by higher generalised self-efficacy level. Or do older age and life experience give higher generalised self-efficacy levels in women diagnosed with osteoporosis? The statistical analyses in our study showed that the higher the age, the lower the generalised self-efficacy level in the examined women.

\section{Conclusions}

1. The vast majority of the respondents were characterised by very low or low generalised self-efficacy level.

2. The generalised self-efficacy level correlates with the duration of osteoporosis treatment, the self-assessment of health status, the frequency of osteoporosis ailments, and the respondents' age and education. The longer the duration of osteoporosis treatment and the better the self-assessment of health status, the higher the generalised self-efficacy level. On the other hand, the more often osteoporosis ailments were experienced, the higher the age, the higher the education level, and the lower the respondents' generalised self-efficacy level.

3. The marital status diversifies the generalised self-efficacy level. The lowest generalised self-efficacy level was found among divorcees and separated women, the intermediate level was found in married women, and the highest level in unmarried women.

4. Women who do not take calcium supplements showed significantly higher generalised self-efficacy level than respondents who take such supplements for osteoporosis treatment. Similar correlation was found with regards to the use of bisphosphonates on a regular basis. 
5. Statistically significant differences were found between the frequency of osteoporosis ailments and chosen health behaviours. The higher the table salt daily intake the more often osteoporosis ailments were experienced. The greater the changes in health behaviours and the more often products rich in vitamin $\mathrm{K}$ were consumed, the less frequently osteoporosis ailments were experienced.

6. The longer the osteoporosis treatment lasted, the more often women consumed food rich in protein, calcium, magnesium, vitamins $\mathrm{D}, \mathrm{K}$, and $\mathrm{C}$, and the lower the daily intake of table salt.

7. Statistically significant differences were found between the frequency of osteoporosis ailments and taking the dietary supplements as well as undertaking health behaviours counteracting osteoporosis. The more often supplements were taken, the less frequently osteoporosis ailments were experienced. Regular physical exercise and taking care of the diet confer rarer experience of osteoporosis ailments.

8. The longer duration of osteoporosis treatment implies the decrease in strong coffee and tea drinking as well as the decrease in cigarette smoking.

9. The more often products rich in calcium, magnesium, protein, vitamin $\mathrm{K}$ and $\mathrm{C}$ were consumed, the better the respondents' self-estimation of the health status was.

\section{Disclosure}

Authors report no conflict of interest.

\section{References}

1. Goluch-Koniuszy Z, Radziszewska M, Dęga S. Ocena sposobu żywienia kobiet w okresie menopauzalnym - zdrowych i z leczoną osteoporoza Folia Pomer Univ Technol Stetin 2010; 15: 5.

2. Trzaska W, Evert LJ, Michalski J. Ilustrowana encyklopedia. Vol. 1. TEM 1925-1932.

3. Lorenc R, Głuszko P, Karczmarewicz E, et al. Zalecenia postępowania diagnostycznego i leczniczego w osteoporozie. Aktualizacja 2013. Med Prakt 2013; 1: 1 .

4. Kanis JA, McCloskey EV, Johansson H, et al. Scientific Advisory Board of the European Society for Clinical and Economic Aspects of Osteoporosis and Osteoarthritis (ESCEO) and the Committee of Scientific Advisors of the International Osteoporosis Foundation (IOF). European guidance for the diagnosis and management of osteoporosis in postmenopausal women. Osteoporosis Int 2013; 24: 23-57.

5. Siris ES, Adler R, Bilezikian J, et al. Kliniczne rozpoznanie osteoporozy: stanowisko. National Bone Health Alliance Working Group Med Prakt 2015; 4: 49.

6. Grywalska E, Grafka A, Putowski L, et al. Komórki macierzyste w leczeniu złamań towarzyszących osteoporozie-medyczne science fiction czy metoda terapii w przyszłości? Menopause Rev 2011; 5: 378-382.

7. Kowalczyk-Nowakowska J, Dmoch-Gajzlerska E. Zagrożenie osteoporozą w wieku perimenopauzalnym. Położna Nauka Praktyka 2009; 2: 12-17.

8. Tryniszewski W, Sobczuk A, Górska-Chrząstek M, et al. Ocena wskaźnika metabolizmu kostnego oraz wyznaczenie zakresu jego wartości prawidłowych u zdrowych kobiet i mężczyzn. Menopause Rev 2011; 1: 51-57.

9. Sewerynek E, Horst-Sikorska W, Stępień-Kłos W. The role of counselling and other factors in compliance of postmenopausal osteoporotic patients to alendronate 70 therapy. Arch Med Sci 2013; 9: 288-296.
10. Wawrzyniak A. Osteoporoza wyzwaniem dla lekarzy rodzinnych. Lekarz Rodzinny 2013; 10: 696-701.

11. Głuszko P. Zalecenia postępowania diagnostyczno-terapeutycznego. Osteoporoza. Reumatologia 2016; 1: 124-128.

12. Marcinkowska-Suchowierska E, Walicka M, Tałałaj M, et al. Osteoporoza - diagnostyka i terapia u osób starszych. Post N Med 2011; 5: 410-411.

13. Europejska Fundacja Osteoporozy i Chorób Mięśniowo-Szkieletowych, Polskie Towarzystwo Ortopedyczne i Traumatologiczne; Raport Osteoporoza - cicha epidemia w Polsce. Kraków 2015.02.10.

14. Dardzińska J, Chabaj-Kędroń H, Małgorzewicz S. Osteoporoza jako choroba społeczna i cywilizacyjna - metody profilaktyki. Hygeia Public Health 2016; 51: 23-30.

15. Janiszewska M, Kulik T, Dziedzic M. Osteoporoza jako problem społeczny - patogeneza, objawy i czynniki ryzyka osteoporozy pomenopauzalnej. Probl Hig Epidemiol 2015; 96: 106-114.

16. Goluch-Koniuszy Z, Radziszewska M, Dęga S. Ocena sposobu żywienia kobiet w okresie menopauzalnym zdrowych i z leczoną osteoporozą. Folia Pomer Univ Technol Stetin 2010; 269: 5-18.

17. Kwiatkowska E. Fitoestrogeny w zapobieganiu osteoporozie. Menopause Rev 2007; 5: 306-309.

18. Gruszczyńska M, Bąk-Sosnowska M, Plinta R. Zachowania zdrowotnej jako istotny element aktywności życiowej człowieka. Stosunek Polaków do własnego zdrowia. Hygeia Public Health 2015; 50: 558-565.

19. Gambin M. Procesy samokontroli a poczucie własnej skuteczności u dzieci z objawami impulsywności - nadaktywności i nieuwagi. Warszawa 2012.

20. Juczyński Z. Poczucie własnej skuteczności - teoria i pomiar. Acta Universitatis Lodziensis Folia Psychologica 2000; 4: 11-23.

21. Kaleńska-Rodzaj J. Poczucie własnej skuteczności muzyka jako wyznacznik efektywnej publicznej prezentacji osiągnięć. Tawrijski Studii 2013; 4: 5-11.

22. Skop-Lewandowska A, Ostachowska-Gąsior A, Kolarzyk E. Żywieniowe czynniki ryzyka osteoporozy u osób w podeszłym wieku. Gerontologia Polska 2012; 20: 53-58.

23. Kruk-Kupiec G. Osteoporoza - poradnik dla pacjentów na przykładzie zaleceń dla pacjentów oddziału IV urazów i schorzeń kręgosłupa i paraplegii urazowej. Piekary Śląskie 2012.

24. Andruszkiewicz A, Banaszkiewicz M, Felsmann M, et al. Poczucie własnej skuteczności a wybrane zmienne związane z funkcjonowaniem zawodowym w grupie pielęgniarek. Probl Pielęg 2011; 19: 145.

25. Chodkiewicz J, Gruszczyńska E. Zmiany dobrostanu psychicznego, poczucia własnej skuteczności oraz strategii radzenia sobie ze stresem w trakcie stacjonarnej terapii osób uzależnionych od alkoholu. Roczniki Psychologiczne 2013; 77.

26. Juczyński Z, Juczyński A. Chcieć to móc, czyli o znaczeniu poczucia własnej skuteczności w modyfikacji zachowań związanych z piciem alkoholu. Alkohol Narkom 2012; 25: 215-221.

27. Lewtak K, Smolińska J. Uogólnione poczucie własnej skuteczności a zachowania antyzdrowotne lekarzy rodzinnych na przykładzie palenia tytoniu. Przegl Epidemiol 2011; 65: 115-121.

28. Rogala D, Mazur A, Maślińska M, et al. Poczucie własnej skuteczności i strategie przystosowania do choroby u pacjentek z nowotworem narządu rodnego. Curr Gynecol Oncol 2015; 13: 154-164. 